\title{
Effective Foreign Language Teaching: Perceptions of Prospective English Language Teachers
}

\author{
Hakan Demiroz ${ }^{1, *}$ Savas Yesilyurt ${ }^{2}$ \\ ${ }^{1}$ Department of English Language Teaching, Faculty of Education, Cumhuriyet University, Turkey \\ ${ }^{2}$ Department of English Language Teaching, Faculty of Education, Atatürk University, Turkey
}

Copyright (C) 2015 by authors, all rights reserved. Authors agree that this article remains permanently open access under the terms of the Creative Commons Attribution License 4.0 International License

\begin{abstract}
Studies conducted so far have mainly focused on investigating the characteristics of effective foreign language teachers to understand the role of teacher effectiveness in the process of language learning, while there is scarcity of studies focusing on the perceptions of the characteristics of effective foreign language teaching of the students of Department of English Language Teaching (ELT) and Department of English Language and Literature (EL\&L) who are the major candidates of English language teaching profession in Turkey. Thus, this study aims to examine the perceptions of prospective English teachers with regard to their department and demographic variables. Effective Teacher Questionnaire [10] was used to obtain data from ELT $(n=212)$ and EL\&L $(n=192)$ students. The $t$ test results indicated that there was a significant difference between ELT students' and EL\&L students' perceptions of an effective foreign language teacher with regard to the mean scores in favor of the former. Also, the $t$ test results indicated that there was a significant difference between daytime students and night-time students with regard to the mean scores. In the light of the findings, some practical recommendations are provided.
\end{abstract}

Keywords English Language Teaching, Effective Teaching, Teachers, Perceptions

\section{Introduction}

Every student has the right to get the most effective education. However, what makes an educational environment/practice effective is a billions question as it is influenced by many factors one of which is the teacher who is at the very center of education. Likewise, defining teacher effectiveness is not an easy undertaking. World Bank's [38] study defined teacher effectiveness "as the capacity of a given teacher to lead their students to sustained achievement gains" (p. 16).

Numerous studies have shown that teacher effectiveness is a crucial factor affecting the students' achievement [22,39]. As research reveals, teacher effectiveness accounts for about 30 percent of the variance in student achievement [19]. Thus, there is a need to explore the characteristics of effective teaching, and informing teachers and teacher educators about these characteristics may help improve the practices [28] and may lead to attain the goals of foreign language teaching.

Given the definition of effective teacher in a general sense, there is a need to make a distinction between the effective foreign language teacher and the effective teachers of other fields of study because foreign language teaching is different from teaching other subjects and it has distinctive characteristics $[8,25]$, especially, with regard to the nature of the process "where the means of the instruction is the subject of instruction" [9, p. 125]. One of the most important components of education; that is foreign language teaching, is not an exception for defining effectiveness. There have been scholarly debates about effective foreign language teaching and there exist several studies [1,2,11,12,17,18,35] about the qualities of effective foreign language teachers and their practices. Bell [7] defines effective foreign language teaching as "clear and enthusiastic teaching that provides learners with the grammatical (syntactical and morphological), lexical, phonological, pragmatic, and sociocultural knowledge and interactive practice they need to communicate successfully in the target language" (p. 260). Understanding the distinctive characteristics of language teachers is crucial for the work of language teacher educators [8]. Werbinska [36] states that in the contemporary educational settings the roles of language teacher are facilitating learning, enabling the learner to learn or preparing the best conditions for learning. Investigating characteristics of an English language teacher is crucial as it is a kind of needs analysis aiming to help teachers improve the quality of their teaching in an attempt to meet their students' needs [33, p. 130]. Thus, the purpose of this study is to investigate the perceptions of prospective English language teachers regarding effective foreign language teaching with respect to their age, gender, GPA, high schools they graduated, grade level, time of classes (daytime and 
night-time), and departments they are studying at (EL\&L vs. ELT). This aim is significant as the graduates of both departments are eligible to become teacher of English in Turkey as in many countries.

\section{Literature Review}

In the last three decades, seeing the importance and benefits of researching teacher effectiveness in foreign language teaching to the teaching process and the parties affected by this process, several researchers have attempted to shed light on this construct. Studies investigating the effectiveness of foreign language teachers revealed results about the personality traits of the teacher, her/his methods of delivering the lesson and his level of information about the foreign language. Brosh [9] investigated the characteristics of effective language teachers as perceived by foreign language teachers and students in Israel with a questionnaire and interviews. The following characteristics emerged from this study:

- Knowledge and command of the target language,

- Ability to organize, explain, and clarify, as well as to arouse and sustain interest and motivation among students,

- Fairness to students by showing neither favoritism nor prejudice,

- Availability to students (p. 133).

Barnes and Lock [3] investigated attributes of effective lecturers of English as a foreign language as perceived by students in a Korean university through a free writing instrument which asked 105 students to write about the attributes of effective English as a foreign language (EFL) lecturers. The results of the study indicated that "1) students feel that lecturer to student rapport is essential to build atmospheres of respect and understanding in EFL classes; 2) existing and prospective lecturers should know that the degree of lecturer enthusiasm and preparation are very obvious to students and major factors influencing classroom atmosphere and motivation; 3 ) diverse views about the type and level of error correction will be a source of conflict unless lecturers make the effort to align student expectations with their own, and be sensitive to student self-esteem; 4) existing and prospective EFL practitioners should be aware that students appreciate their efforts to employ a participatory approach" (pp. 148-9).

Wichadee and Orawiwatnakul [37] collected data with a questionnaire from 192 students at Bangkok University. The results of their study indicated that both low and high proficiency students rated "effective language teacher skills" in order of importance as follows: organization and communication skills, socio-affective skills, and organization and communication skills. In a recent paper, Salahshour and Hajizadeh [29] attempted to shed light on characteristics of effective EFL instructors through a 58-item questionnaire in Iran. They listed some of the most important features of an effective and successful EFL teacher as follows:

- Having interest in his/her job

- Having a sense of responsibility towards his/her job

- Being enthusiastic and lively

- Being self-confident

- Being punctual

- Encouraging students to use the target language at all times

- Providing explicit grammar correction

- Providing detailed explanation during reading and listening tasks

- Emphasizing frequent oral quizzes

- Emphasizing all skills, especially speaking

- Having knowledge of subject matter

- Having the ability to communicate ideas effectively

- Having the ability to answer the students' questions

- Having respect for students

- Being kind and friendly

- Encouraging participation

- Creating motivation in students

- Helping to increase the students' self-confidence during learning

- Taking students' feedback about the class into consideration

- Using the class time wisely

- Maintaining class order (p. 172).

In another study, Brown [10], investigated approximately 1600 students' and 49 teachers' perceptions of effective foreign language teaching through a 24 -item questionnaire at the University of Arizona. The results of the study indicated that the students are in favor of a grammar-based approach whereas their teachers preferred a more communicative classroom. The results of the study also pointed to the need for foreign language teachers to seek out their students' perspectives actively and to engage them in brief classroom discussions about the rationale behind certain instructional strategies (p. 46).

As for the Turkish context, where English is the commonest of foreign languages taught in educational settings $[4-6,15,24,32]$, there have been several substantial studies investigating the EFL students' perceptions of effective foreign language teachers. The results of these studies revealed that students expect their teachers to have a good command of both English and its culture, to have fluency in English, to be friendly, to use visual materials and technology in the classroom, to have good personal characteristics, having personal strategies to teach, creating a positive learning environment and so on $[13,14,30]$.

In order to identify the characteristics of effective foreign language teachers Arıkan, Taşer and Saraç-Süzer [2] investigated conceptualization of an effective English language teacher of Turkish learners of EFL. Their study concluded that an effective teacher is a friendly, young, enthusiastic, creative, and humorous person whose gender is not important. The students expect the teacher to be fluent in English, to play educational games, and to teach grammar effectively by using real life situations to explain language 
items.

Arıkan [1] investigated the ideal and actual characteristics of an effective English language teacher from the perspectives of prospective and in-service teachers of English through a mixed method study. The participants of the study were 4 pre-service teachers, 3 in-service teachers and 50 additional pre-service teachers who filled in a survey. The findings of the study revealed that on the one hand the prospective teachers did not regard their mentors (in-service teachers) effective, on the other, in-service teachers contend that their ineffectiveness stem from not having proper in-service training programs and an updated curriculum.

In another study carried out in the Turkish context, Çubukcu [12], collected data from 90 participants who were majoring in ELT in the western part of Turkey through journals written reflectively on a daily basis. The results of the study delineated that the most important quality that the teachers should have was the affective side; caring about students and their learning. Besides, quality English language teachers should use various instructional methods in their classroom, which is a relaxed environment, and they should fulfil the needs of students with regard to learning, motivation, and interests.

Korkmaz and Yavuz [23] explored the competencies required to be an effective teacher of English from the perspective of $4^{\text {th }}$ year ELT student-teachers $(\mathrm{N}=100 ; \mathrm{M}=23$, $\mathrm{F}=77$ ). The study obtained data with an open-ended question, a structured questionnaire and interviews. The results of the study revealed 50 points with regard to competencies: monitoring and evaluation of learning and development which were knowing the student; knowledge of curriculum and content; learning and teaching process; personal and professional values-professional development; school-family and society relationships.

Simpson and Mengi [34] investigated the perceptions of 31 intermediate students of English and 30 participants (English teachers, academicians, and English teacher candidates). The results of this qualitative investigation revealed that students expect their teachers to speak English all the time; to get students to speak English; to teach in a funny way; to teach the lesson in a fluent and organized manner; to be honest, fair, creative, enjoyable, helpful, energetic, likable, empathetic; to have a good academic career; to use technology, to be a good classroom manager; to give and check homework.

Çelik, Arıkan, and Caner [11] asked about the qualities they believed to be the characteristics of a successful English language teacher through a survey to 998 undergraduate students who are taking English courses at a state university in Turkey. Their results showed that the students gave the highest scores to the attributes of being fair and just (3.74) as well as showing enthusiasm (3.72). These qualities were followed by personal traits such as friendliness (3.49), being loving (3.47), creativity (3.46), and being experienced (3.17). In addition, being humorous (3.08) and being Turkish, but good at English (3.05) were reported as being important characteristics of an effective foreign language teacher. The least significant items included being young (2.00), having lived in a foreign country (1.95), being a native speaker of English (1.57), and being a male or a female (1.40).

As this literature review demonstrates, there is a lack of studies comparing the beliefs of students who are majoring at different fields of study and who are eligible to teach English after graduation. This comparison is important because their field of study may be influential in forming their teaching competencies and cognition. Thus, in an attempt to cover this gap in the literature, the present study addresses the beliefs of Turkish prospective teachers of English from the department of English Language Teaching (ELT) and the department of English Language and Literature (EL\&L). The graduates of the latter are eligible to teach English after attending a non-thesis pedagogical course in faculties of education within the scope of a Pedagogical Formation Certificate Program [a course lasting one year which is a requisite for the graduates of departments other than ELT to become a teacher of English language] (Higher Education Council of Turkey (YÖK), Pedagojik Formasyon Eğitimi Sertifika Programına İlişkin Usul ve Esaslar) [20].

This study aims to research the perceptions of the prospective teachers of English on effective foreign language teaching. This investigation is significant because the prospective teachers will teach English and their perceptions are substantial in shaping their teaching cognition and practices. The outcomes of this investigation may provide useful implications for teachers, teacher trainers, policymakers, curriculum developers, and pre-service teachers especially in Turkey and partially in other EFL contexts. They may serve as a preliminary needs analysis of the initial teacher education system in the particular context.

This study attempts to answer the research questions below.

1) What are the perceptions of prospective English language teachers regarding effective foreign language teaching?

2) Do their perceptions differ with regard to their age, gender, GPA, high schools they graduated, grade level, time of classes (daytime and night-time), and departments (EL\&L vs. ELT)?

\section{Method}

\subsection{Design}

This study is a quantitative survey since it comprises of data collection through a questionnaire aiming to describe the perceptions of pre-service EFL teachers regarding the characteristics of effective English language teachers. As Gay, Mills and Airasian [16] state "survey research can be used to gather information about a group's beliefs, attitudes, behaviors, and demographic composition" (p. 184).

\subsection{Participants}

The participants of the study were selected on the basis of convenience sampling $[16,21]$ which is the process of 
including whoever happens to be available in the sample at the time of research. The participants $(\mathrm{N}=404 ; \mathrm{F}=309, \mathrm{M}=95)$ of the study were ELT department students $(n=212)$ from a state university in the Eastern Anatolia Region of Turkey and EL\&L ( $n=192)$ department students from a state university in the eastern part of Middle Anatolia Region of Turkey (See Table 1). The proportion between the genders is reflective of the general population distribution in the departments. This sample size is claimed to be acceptable as the sample size above 400 can be regarded as a safe sample [16, p. 139].

Table 1. Distribution of the participants by department, gender, and age

\begin{tabular}{|c|c|c|c|c|c|c|c|}
\hline \multirow{2}{*}{\multicolumn{3}{|c|}{ Department }} & \multicolumn{4}{|c|}{ Age } & \multirow{3}{*}{$\begin{array}{c}\text { Total } \\
174\end{array}$} \\
\hline & & & \multirow{2}{*}{$\frac{17-18}{13}$} & \multirow{2}{*}{$\begin{array}{c}19-20 \\
47\end{array}$} & \multirow{2}{*}{$\frac{21-22}{67}$} & \multirow{2}{*}{$\frac{23+}{47}$} & \\
\hline \multirow{3}{*}{ ELT } & \multirow{2}{*}{ Gender } & Female & & & & & \\
\hline & & Male & 1 & 12 & 12 & 13 & 38 \\
\hline & \multicolumn{2}{|c|}{ Total } & 14 & 59 & 79 & 60 & 212 \\
\hline \multirow{3}{*}{ EL\&L } & \multirow{2}{*}{ Gender } & Female & 7 & 51 & 48 & 29 & 135 \\
\hline & & Male & 4 & 20 & 17 & 16 & 57 \\
\hline & \multicolumn{2}{|c|}{ Total } & 11 & 71 & 65 & 45 & 192 \\
\hline \multicolumn{3}{|c|}{ Total } & 25 & 130 & 144 & 105 & 404 \\
\hline
\end{tabular}

In order to be selected as a student for both departments, the students have to take two examinations, YGS (Yükseköğretime Geçiş Sınavi; Higher Education Entrance Examination) and LYS (Lisans Yerleştirme Sınavi; Undergraduate Placement Examination), carried out by ÖSYM (Student Selection Centre of Turkey) [27]. In the first examination students are asked questions of various subjects such as Turkish, Math, Sciences, and Social Sciences. After passing the first step, three months later, they take another examination which comprises a part (LYS-5) testing their command of English through reading comprehension, vocabulary, translation from and to English and structure questions. Once they are selected as students to these departments, they have to take a preparatory class exemption exam. The ones who achieve this exam become freshmen and the ones who fail have to take an intensive preparatory class until they succeed. The students of ELT and EL\&L departments were chosen as participants because after graduating they will become EFL teachers and they would reflect on the issue under study during their profession.

\subsection{Instrument}

Effective Teacher Questionnaire [10] was utilized in order to collect data from ELT and EL\&L students. The questionnaire comprises 24 Likert-type items which are anchored at $1=$ "Strongly Disagree," 2= "Disagree," 3= "Agree," 4= "Strongly Agree." The questionnaire comprises the following categories: Grammar Teaching $(10,16,18,20)$, Error Correction (5, 8, 13), Target Language Use (7, 14, 17, 19, 22, 23), Culture $(3,9,21)$, Computer-Based Technology (1), Communicative Language Teaching Strategies $(11,12,2$, $4,15,21,23,24)$, and Assessment $(2,6,10,23)$. Also, the participants were asked to fill in the items intended to gather demographic information such as gender, age, department, high school they graduated, and their GPAs.

\subsection{Data Collection}

Data collection commenced with informing the participants about completely voluntary nature of the study. All ethical issues were taken into consideration in order not to give any harm to anyone. They were told they could withdraw whenever they wanted. The researchers, who themselves collected the data, explained to the participants that the questionnaire was about their perceptions about the characteristics of an effective foreign language teacher. The participants were assured that it was not a test and there were no right or wrong answers and all their responses to the questionnaire would be kept confidential and the information obtained would not be identified as to any participant. They were also told that the researchers would be the only persons with access to individual questionnaires which would be anonymous at the student level. The participants were asked for sincere and personal responses so as to guarantee the success of the study. It took about 15 minutes to administer the questionnaire.

\section{Results}

Results concerning the prospective English language teachers' perceptions of effective foreign language teaching are given in this section of the study. As the data of the study comes from a Likert-type questionnaire filled in by the participants of the study, it was analyzed by using statistical procedures, namely, independent samples $t$ test, analysis of variance (ANOVA), and post hoc analysis using the Scheffe test by means of SPSS 16 software.

Table 2. A comparison of the mean survey scores across genders

\begin{tabular}{|c|c|c|c|c|c|c|c|}
\hline \multicolumn{2}{|c|}{ Gender } & $\mathrm{n}$ & $\overline{\mathrm{x}}$ & $s d$ & $\overline{\mathrm{x}} 1-\overline{\mathrm{x}} 2$ & $t$ & $p$ \\
\hline \multirow{2}{*}{$\begin{array}{c}\text { Mean } \\
\text { Scores }\end{array}$} & Female & 309 & 2.95 & 0.25 & \multirow{2}{*}{0.04} & 1.35 & 0.18 \\
\cline { 2 - 5 } & Male & 95 & 2.91 & 0.26 & & & \\
\hline
\end{tabular}

An independent-samples $t$ test was conducted to evaluate whether participants' mean scores differed across genders at statistically significant levels. The $t$ test results indicated that there was not a significant difference between females $(\mathrm{M}=$ $2.95, \mathrm{SD}=0.25)$ and males $(\mathrm{M}=2.91, \mathrm{SD}=0.26)$ with regard to the mean scores, $t(402)=1.35, \mathrm{p}=0.18$ (See Table 2 ). In order to test whether daytime and night-time students' mean scores differed at statistically significant levels, an independent-samples $t$ test was conducted. The $t$ test results indicated that there was a significant difference between daytime students $(\mathrm{M}=2,96, \mathrm{SD}=0.26)$ and night-time students $(\mathrm{M}=2.87, \mathrm{SD}=0,22)$ with regard to the mean scores, $\mathrm{t}(402)=3.05 \mathrm{p}=.001$.

An independent-samples $t$ test was conducted to test whether ELT and EL\&L students' mean scores for the 
questionnaire items differed. The $t$ test results indicated that there was a significant difference between ELT students (M $=2.99, \mathrm{SD}=0.27)$ and EL\&L students $(\mathrm{M}=2.89, \mathrm{SD}=0.23)$ with regard to the mean scores in favor of the former, $t$ (402) $=4.08, \mathrm{p}=0.001$ (See Table 3 ). Before carrying out one-way ANOVA analyses, homogeneity of variances and normality of distribution of data assumptions were checked and it was found that the scores in the datasets were normally distributed and the variances were equal. This ensured that ANOVA could be carried out. A one-way analysis of variance revealed that the participants' mean scores did not significantly differ with respect to their GPA scores $[F(4$, $263)=2.16, p=.07)]$, the high schools that they graduated from $[\mathrm{F}(4,399)=0.94, \mathrm{p}=.44)]$, and their age $[\mathrm{F}(3,400)=$ $2.34, \mathrm{p}=.07)]$.

Table 3. A comparison of the mean survey scores across departments

\begin{tabular}{|c|c|c|c|c|c|c|c|}
\hline & Dept. & $\mathrm{N}$ & $\overline{\mathrm{x}}$ & $s d$ & $\overline{\mathrm{x}} 1-\overline{\mathrm{x}} 2$ & $t$ & $p$ \\
\hline \multirow{2}{*}{$\begin{array}{c}\text { Mean } \\
\text { Scores }\end{array}$} & ELT & 212 & 2.99 & 0.27 & \multirow{2}{*}{0.10} & \multirow{2}{*}{4.08} & \multirow{2}{*}{0.001} \\
\cline { 2 - 6 } & EL\&L & 192 & 2.89 & 0.23 & & & \\
\hline
\end{tabular}

Although GPA, high school graduation, and age did not have a statistically significant difference in the participants' mean scores, the participants' scores differed significantly with respect to grade level (prep students, freshmen, sophomores, juniors and seniors) $[F(4,399)=3.38, \mathrm{p}=.01]$. Post hoc analysis using the Scheffe test revealed that the mean survey scores of the third-year students $(M=2.98, S D$ $=0.23$ ) were significantly higher than those of the first-year students $(M=2.85, S D=0.32)$. This finding suggested that as grade levels of the participants get higher, their perceptions of the effective teacher of English change and they expect more effective teacher skills from their teachers. Also, it must be noted that this finding may suggest that as the grade levels get higher they become acquainted with more lecturers who have various characteristics as teachers, and the students can be modeling them, and they may have a better understanding of the teacher characteristics.

When the mean scores for the subscales (computer-based technology, assessment, culture, communicative language teaching, target language use, error correction and grammar teaching) were assessed in terms of various demographic variables (age, gender and department) and time of the classes, it was found that the scores consistently differed in three of the subscales at a statistically significant level. There was a significant difference between age groups as determined by one-way ANOVA for the subscale of culture,
$F(3,400)=3.25, \mathrm{p}=.022$; post hoc analysis using the Scheffe test revealed that the mean score for the age group 21-22 $(M=3.29, S D=0.43)$ was significantly higher than that of the age group 19-20 $(M=3.11, S D=0.50)$. Similarly, there was a significant difference between age groups as determined by one-way ANOVA for the subscale of communicative language teaching, $F(3,400)=3.61, \mathrm{p}=.013$. Post hoc analysis using the Scheffe test revealed that the mean score for the age group 21-22 $(M=3.05, S D=0.35)$ was significantly higher than that of the age group 19-20 (M $=2.94, S D=0.35$ ). Finally, there was again a significant difference between age groups for the subscale of error correction, $F(3,400)=5.02, \mathrm{p}=.002$ and the post hoc analysis using the Scheffe test revealed that the mean score for the age group 21-22 $(M=2.91, S D=0.49)$ was significantly higher than that of the age group 19-20 $(M=$ $2.68, S D=0.50)$. Moreover, the type of graduation had a significant impact on the learners' mean scores for the grammar teaching subscale, $F(4,399)=2.91, \mathrm{p}=.021$. Post hoc analysis using the Scheffe test revealed that the mean score for vocational high school $(\mathrm{M}=3.50, \mathrm{SD}=0.18)$ was significantly higher than those of high school $(\mathrm{M}=2.87, \mathrm{SD}$ $=0.42)$, Anatolian high school $(\mathrm{M}=2.87, \mathrm{SD}=0.44)$ and other schools $(\mathrm{M}=2.83, \mathrm{SD}=0.40)$. This finding suggests that graduates of vocational high schools expect their teachers to teach English focusing more on form and structure.

On the other hand, ANOVA results also indicated that there was not a statistically significant difference for the remaining subscales; that is, computer-based technology, assessment and target language use with respect to none of the variables mentioned (age, GPA and high school graduation), and grammar teaching with respect to age and GPA. Independent samples $t$-tests were carried out to test the effect of bi-polar variables (gender, department and time of the classes) on students' mean scores for each subscale. The results indicated that in terms of culture subscale there was a statistically significant difference between the mean scores of males $(\mathrm{M}=3.10, \mathrm{SD}=0.45)$ and that of females $(\mathrm{M}=3.22$, $\mathrm{SD}=0.48)$ in favor of the latter, $t(402)=2.09, p=0.037$ (See Table 4); the results also indicated that there was a significant difference between ELT students $(\mathrm{M}=3.25, \mathrm{SD}=$ $0.47)$ and EL\&L students $(\mathrm{M}=3.14, \mathrm{SD}=0.47)$ in favor of the former, $t(402)=2.44, p=0.015$ (See Table 4$)$; and finally between the scores of daytime students $(\mathrm{M}=3.24, \mathrm{SD}=0.47)$ and night-time students $(\mathrm{M}=3.05, \mathrm{SD}=0.44)$ in favor of the former, $t(402)=3.48, p=0.001$.

Table 4. A comparison of the mean scores for the subscale of culture (With respect to gender, department, and time of classes)

\begin{tabular}{|c|c|c|c|c|c|c|c|}
\hline Variable & & $\mathrm{N}$ & $\overline{\mathrm{x}}$ & sd & $\overline{\mathrm{x}} 1-\overline{\mathrm{x}} 2$ & $\mathrm{t}$ & $\mathrm{P}$ \\
\hline \multirow{2}{*}{ Gender } & Female & 309 & 3.22 & 0.48 & \multirow{2}{*}{0.11561} & \multirow{2}{*}{2.09} & \multirow{2}{*}{0.037} \\
\hline & Male & 95 & 3.10 & 0.45 & & & \\
\hline \multirow{2}{*}{ Department } & ELT & 212 & 3.25 & 0.47 & \multirow{2}{*}{0.11442} & \multirow{2}{*}{2.44} & \multirow{2}{*}{0.015} \\
\hline & EL\&L & 192 & 3.14 & 0.47 & & & \\
\hline \multirow{2}{*}{$\begin{array}{l}\text { Time of } \\
\text { Classes }\end{array}$} & Daytime & 306 & 3.24 & 0.47 & \multirow{2}{*}{0.18850} & \multirow{2}{*}{3.48} & \multirow{2}{*}{0.001} \\
\hline & Night-time & 98 & 3.05 & 0.44 & & & \\
\hline
\end{tabular}


Table 5. A comparison of the mean scores for the subscale of communicative language teaching (With respect to gender, department and time of the classes)

\begin{tabular}{|c|c|c|c|c|c|c|c|}
\hline Variable & & $\mathrm{N}$ & $\overline{\mathrm{x}}$ & $\mathrm{SD}$ & $\overline{\mathrm{x}} 1-\overline{\mathrm{x}} 2$ & $t$ & $p$ \\
\hline \multirow{2}{*}{ Gender } & Female & 309 & 3.03 & 0.34 & \multirow{2}{*}{0.10655} & \multirow{2}{*}{2.66} & 0.008 \\
\cline { 2 - 8 } & Male & 95 & 2.92 & 0.34 & & \multirow{2}{*}{0.65} & 0.001 \\
\hline \multirow{2}{*}{ Department } & ELT & 212 & 3.06 & 0.36 & \multirow{2}{*}{0.12280} & 3.65 \\
\cline { 2 - 9 } Time of Classes & EL\&L & 192 & 2.94 & 0.31 & & \multirow{2}{*}{0.008} \\
\cline { 2 - 9 } & Day & 306 & 3.03 & 0.34 & \multirow{2}{*}{0.10625} & 2.69 & 0.32 \\
\hline
\end{tabular}

Table 6. A comparison of the mean scores for the subscale of error correction (With respect to department and time of the classes)

\begin{tabular}{|c|c|c|c|c|c|c|c|}
\hline Variable & & $\mathrm{N}$ & $\overline{\mathrm{x}}$ & $s d$ & $\overline{\mathrm{x}} 1-\overline{\mathrm{x}} 2$ & $t$ & $p$ \\
\hline \multirow{2}{*}{ Department } & ELT & 212 & 2.87 & 0.49 & \multirow{2}{*}{0.13132} & \multirow{2}{*}{4.08} & \multirow{2}{*}{$\begin{array}{l}0.0 \\
01\end{array}$} \\
\hline & EL\&L & 192 & 2.74 & 0.53 & & & \\
\hline \multirow{2}{*}{$\begin{array}{l}\text { Time of } \\
\text { Classes }\end{array}$} & Daytime & 306 & 2.85 & 0.50 & \multirow{2}{*}{0.20301} & \multirow{2}{*}{2.59} & 0.0 \\
\hline & Night-time & 98 & 2.65 & 0.53 & & & 10 \\
\hline
\end{tabular}

As shown in Table 5, the results indicated that in terms of communicative language teaching subscale there was a statistically significant difference between the mean scores of males $(\mathrm{M}=2.92, \mathrm{SD}=0.34)$ and that of females $(\mathrm{M}=3.03$, $\mathrm{SD}=0.34)$ in favor of the latter, $\mathrm{t}(402)=2.66, \mathrm{p}=0.008$; between ELT students $(\mathrm{M}=3.06, \mathrm{SD}=0.36)$ and $\mathrm{EL} \& \mathrm{~L}$ students $(\mathrm{M}=2.94, \mathrm{SD}=0.31)$ in favor of the former, $\mathrm{t}(402)$ $=3.65, \mathrm{p}=0.001$ (See Table 5); and finally between the scores of daytime $(\mathrm{M}=3.03, \mathrm{SD}=0.34)$ and night-time students $(\mathrm{M}=2.92, \mathrm{SD}=0.32)$ in favor of the former, $\mathrm{t}(402)$ $=2.69, \mathrm{p}=0.008$.

As can be seen in Table 6, the results indicated that in terms of error correction subscale there was a significant difference between ELT students $(\mathrm{M}=2.87, \mathrm{SD}=0.49)$ and EL\&L students $(\mathrm{M}=2.74, \mathrm{SD}=0.53)$ in favor of the former, $t(402)=4.08, p=0.001$ and between the scores of daytime $(\mathrm{M}=2.85, \mathrm{SD}=0.50)$ and night-time students $(\mathrm{M}=2.65, \mathrm{SD}$ $=0.53)$ in favor of the former, $t(402)=2.59, p=0.010$

\section{Discussion and Conclusions}

In this study we aimed to gather data on how Turkish prospective ELT teachers perceive characteristics of an effective foreign language teacher. The findings of the study, in line with the previous studies $[1,11,12]$, show that ELT department, female, and daytime students have perceptions that an effective foreign language teacher should teach communicatively. The participants from the ELT department believe that effective foreign language teachers should correct students indirectly when they produce oral errors instead of resorting to direct correction (e.g., correctly repeating back to them rather than directly stating that they are incorrect). They also believe that an effective foreign language teacher should have a good command of the target culture.

Another finding suggests that the participants from the ELT department perceive an effective foreign language teacher in a different way from the EL\&L students do. This difference may stem from the courses on the curricula of the two departments which are considerably different. The ELT department students take a total of 155 credit courses to graduate during their 4-year BA program. 33 credits out of 155 are related to Educational Sciences while 40 credits out of 155 are related to Foreign Language Education (FLE). When the curriculum of the EL\&L department is investigated, it is seen that the students have to take a total of 182 credit courses during their 4-year study to gain the BA degree. 6 credits out of 182 are related to FLE. However, as it was noted earlier that the graduates of EL\&L department have to take Pedagogical Formation Certificate Program which is 25 credits for two semesters. This program offers 11 credits courses related to FLE. The difference of the courses with regard to content and quantity of credits taken during their studies at their departments may cause different perceptions of effective foreign language teachers. In addition, the prospective teachers from the ELT department have more practicum courses through which they have the opportunity to be involved in observing and working in their field of study and using the knowledge and skills that they have learned at their department. This also gives them the chance of meeting effective foreign language teachers in the schools where they practice teaching.

The participants from the ELT department evaluate the foreign language teachers who allow the use of mother tongue in responding to test questions, give priority to indirect correction, teach the language by having students complete specific tasks rather than grammar-focused exercises, have students respond to commands physically in the foreign language, speak the foreign language with native-like control of both grammar and accent significantly, and who are knowledgeable about the culture of the target language more effective than those from the EL\&L department do. The participants from the EL\&L department give greater importance to activities that practice specific grammar points rather than activities whose goal is merely to 
exchange information, which is in line with the results of Brown [10], and [11] which found that Turkish students learning English attached importance to effective teaching of grammar. This variation in perceptions about teaching a foreign language communicatively versus traditional methods favoring grammar-based approaches may stem from the educational backgrounds of the students as in Turkey there is a considerable number of teachers of English favoring to teach with an emphasis on grammatical structures and form of the language.

As for the finding concerning the gender difference revealed by the communicative language teaching subscale of the questionnaire, female students placed more weight on effective teacher characteristics related to teaching English using communicative language teaching strategies such as assigning group tasks, pair work, and project-based learning. This finding is in line with Park and Lee [28] who reported that female students demonstrated different characteristics in socio-affective skills as effective English teacher qualities. It is also congruent with Yilmaz [39] who reported the differences between male and female prospective English teachers' perceptions with regard to influences of effective teachers on their success and their career choice.

Another finding of this study suggests that the daytime students and night-time students have different perceptions of effective foreign language teaching. In contrast to some previous studies $[28,37]$ which found statistically significant differences between low and high proficiency groups in pedagogical knowledge, socio-affective skills, and organization and communication skills, this present study revealed no significant difference with regard to participants' GPAs.

As discussed above, since teacher effectiveness is a crucial element of education and it plays a major role on students' achievement, skills of an effective teacher of English should be taught to prospective teachers in their teaching methodology courses. Teacher educators should recommend that prospective teachers observe and reflect on in-service teachers' characteristics especially in their practicum courses. Also, prospective teachers can be provided with the opportunity to use micro teaching activities in order to enhance their reflection on their own and peers' teaching styles and teaching strategies, and these activities may help them learn new teaching techniques and methods [26]. In addition, these microteaching activities can accompany video recordings after which student teachers are encouraged to discuss the strengths and weaknesses of the particular microteaching session, through which teacher educators may augment participation, self-evaluation, reflection, collaboration and interaction among prospective teachers [31]. The educators of prospective teachers may integrate digital videos prepared for the methodology courses into their methodology and relevant courses. Through in-service training, teachers of English language should be reminded of these characteristics and they should be recommended to attempt to include these characteristics into their teaching.
This study is limited to 404 participants from only two state universities in Turkey where English is taught as a foreign language and the data of the study is collected by a questionnaire and analyzed quantitatively. Since there is no empirical evidence for the correlation between the prospective teachers' perceptions of the effective foreign language teachers and their GPAs, further studies may focus on investigating the university entrance exam scores of the students, especially their scores of English test (LYS-5), with regard to their GPAs, time of the classes, and other variables. Another limitation of this study is that it has collected data at one time. Further studies can be designed with a longitudinal approach; that is to say, data can be collected from the prospective teachers and they may be compared to the data collected after they become in-service teachers, so as to analyze whether there is a perceptual change. To further our understanding of perceptions of the prospective teachers of English from different majors, characteristics of effective foreign language teachers can be investigated through designing qualitative and mixed method studies which can provide in-depth analysis of the participants' experiences.

\section{Acknowledgements}

We would like to thank the prospective teachers who participated in this study, and the reviewers who added much to this paper. The preliminary results and summary of this study was presented at II nd International Eurasian Educational Research Congress, Hacettepe University, Ankara. (8-10 June, 2015).

\section{REFERENCES}

[1] Arrkan, A. (2010). Effective English language teacher from the perspectives of prospective and in-service teachers in Turkey. Elektronik Sosyal Bilimler Dergisi (Electronic Journal of Social Sciences), 9(31), 209-223.

[2] Arıkan, A., Taşer, D., \& Saraç-Süzer, H. S. (2008). The effective English language teacher from the perspectives of Turkish preparatory school students. Education and Science, 33(150), 42-51.

[3] Barnes, B. D., \& Lock, E. C. (2010). The attributes of effective lecturers of English as a foreign language as perceived by students in a Korean university. Australian Journal of Teacher Education, 35(1), 139-152. doi:10.14221/ajte. 2010v35n1.2

[4] Bayyurt, Y. (2010). A sociolinguistic profile of Turkey, Northern Cyprus and other Turkic States in Central Asia. In M. J. Ball (Ed.), The Routledge handbook of sociolinguistics around the world (pp. 117-126). London: Routledge.

[5] Bayyurt, Y. (2012). Proposing a model for English language education in the Turkish socio-cultural context. In Y. Bayyurt \& Y. Bektaş-Çetinkaya (Eds.), Research Perspectives on Teaching and Learning English in Turkey: Policies and Practices (pp. 301-312). Frankfurt: Peter Lang. 
[6] Bayyurt, Y. (2013). Current perspectives on sociolinguistics and English language education. The Journal of Language Teaching and Learning, 3(1), 69-78

[7] Bell, T. R. (2005). Behaviours and attitudes of effective foreign language teachers: Results of a questionnaire study. Foreign Language Annals, 38(2), 259-270. doi: $10.1111 / \mathrm{j} .1944-9720.2005$. tb02490.x

[8] Borg, S. (2006). The distinctive characteristics of foreign language teachers. Language Teaching Research, 10(1), 3-31. doi: 10.1191/ 1362168806 lr182oa

[9] Brosh, H. (1996). Perceived characteristics of the effective language teacher. Foreign Language Annals, 29(2), 125-136. doi: 10.1111/j.1944-9720. 1996.tb02322.x

[10] Brown, A. V. (2009). Students' and teachers' perceptions of effective foreign language teaching: A comparison of ideals. The Modern Language Journal, 93(1), 46-60. doi: 10.1111/j.1540-4781. 2009.00827.x

[11] Çelik, S., Arıkan, A., \&, Caner, M. (2013). In the eyes of Turkish EFL learners: What makes an effective foreign language teacher? Porta Linguarum, 20, 287-297.

[12] Çubukcu, F. (2010). Student teachers' perceptions of teacher competence and their attributions for success and failure in learning. The Journal of International Social Research (Uluslararası Sosyal Araştırmalar Dergisi), 3(10), 213-217.

[13] Demirel, Ö. (1989). Yabanc1 dil öğretmenlerinin yeterlikleri, Hacettepe Üniversitesi Ĕgitim Fakültesi Dergisi (Hacettepe University Journal of Education), 4, 5-26.

[14] Demirel, Ö. (1990). Yabancı dil öğretmenlerinin yeterlikleri, Hacettepe Üniversitesi Eğitim Fakültesi Dergisi (Hacettepe University Journal of Education), 5, 133-163.

[15] Doğançay-Aktuna, S., \& Kizıltepe, Z. (2005). English in Turkey. World Englishes, 24(2), 253-267. doi:10.1111/j.1467-971X.2005.00408.x

[16] Gay, L. R., Mills, G. E., \& Airasian, P. (2012). Educational research: Competencies for analysis and application. Upper Saddle River, NJ: Pearson.

[17] Gordon, E. J. (1973). The effective English teacher. The English Journal, 62(3), 448-453.

[18] Harris, J., \& O’Duibhir, P. (2011). Effective Language Teaching: A Synthesis of Research. Dublin: National Council for Curriculum and Assessment /Report No: 13). Retrieved from

http://www.ncca.ie/en/Publications/Reports/Effective_langu age_teaching_a_synthesis_of_research.pdf

[19] Hattie, J. (2003, October). Teachers make a difference: What is the research evidence? Paper presented at Australian Council for Educational Research Annual Conference on Building Teacher Quality, Camberwell, Australia.

[20] Higher Education Council of Turkey (YÖK), Pedagojik Formasyon Eğitimi Sertifika Programına İlişkin Usul Ve Esaslar). Retrieved from http://www.yok.gov.tr/web/guest/icerik/-/journal content/56_INSTANCE_rEHF8BIsfYRx/10279/7052802

[21] Johnson, B, \& Christensen, L. (2012). Educational research: Quantitative, qualitative, and mixed approaches (4th ed.). Thousand Oaks, Ca: Sage.

[22] Ketsman, O. (2012). Expectations in the foreign language classrooms: A case study. The Qualitative Report, 17(Art. 106), 1-21. Retrieved from

http://www.nova.edu/ssss/QR/QR17/ketsman.pdf

[23] Korkmaz, Ş. Ç., \& Yavuz, A. (2011). ELT student teachers' perspectives of an effective English teacher. Journal of Theory and Practice in Education, 7(2), 207-229.

[24] Kırkgöz, Y. (2009). Globalization and English language policy in Turkey. Educational Policy, 23(5), 663-684. doi:10.1177/0895904808316319

[25] Lee, J. J. (2010). The uniqueness of EFL teachers: perceptions of Japanese learners. TESOL Journal, 1(1), 23-48. http://dx.doi.org/10.5054/tj.2010. 214881

[26] Ogeyik, M. C. (2009). Attitudes of the student teachers in English language teaching programs towards microteaching technique. English Language Teaching, 2(3). doi: 10.5539/elt.v2n3 p205

[27] OSYM. 2015-ÖSYS: Öğrenci Seçme ve Yerleştirme Sistemi. http://dokuman.osym.gov. tr/pdfdokuman /2015/OSYS/OSYS2015Yerlestirme MinMaxTablo-423072015.pdf

[28] Park, G. P., \& Lee, H. W. (2006). The characteristics of effective English teachers as perceived by high school teachers and students in Korea. Asia Pacific Education Review, 7(2), 236-248. doi:10.1007/ BF03031547

[29] Salahshour, N., \& Hajizadeh, N. (2013). Characteristics of effective EFL instructors. Procedia - Social and Behavioral Sciences, 70(2013), 163-173. doi:10.1016/j.sbspro.2013.01. 052

[30] Saraç-Süzer, H. S. (2007). Examining the methodological issues through pedagogical and practical knowledge of experienced teachers: A case study (Unpublished doctoral dissertation). Hacettepe University, Ankara, Turkey.

[31] Savaş, P. (2012). Use of digital video recording in the preparation stage of pre-service foreign language teachers' micro-teachings. International Journal on New Trends in Education and Their Implications, 3(3), 107-116. Retrieved from http://www.ijonte.org/FileUpload/ks63207/File/ 11. savas.pdf

[32] Selvi, A. F. (2011) World Englishes in the Turkish sociolinguistic context. World Englishes, 30(2), 182-199. doi: 10.1111/j.1467-971X.2011.01705.x

[33] Shishavan, H. B., \& Sadeghi, K. (2009). Characteristics of an effective English language teacher as perceived by Iranian teachers and learners of English. English Language Teaching, 2(4), 130-143. doi:10.5539/elt.v2n4p130

[34] Simpson, S., \& Mengi, E. (February, 2011). What are the characteristics of a good teacher? Paper presented at 15 th International INGED Conference: "Taking It to the Limits", Ankara, Turkey. Retrieved February 25, 2013 from https://research.

sabanciuniv.edu/18886/1/Perceptions_of the Exemplary_Te acher_INGED_(2011).pdf.

[35] Taqi, H. A., Al-Nouh, N. A., \& Akbar, R. S. (2014). The perspectives of students in the college of basic education on the characteristics of effective English language teachers. English Language Teaching, 7(3), 121-133. doi:10.5539/elt.v7n3p121 
[36] Werbinska, D. (2009). A profile of an effective teacher of English: a qualitative study from Poland. Hacettepe Üniversitesi Ĕgitim Fakültesi Dergisi (Hacettepe University Journal of Education), 36, 306-315.

[37] Wichadee, S., \& Orawiwatnakul, W. (2012). Characteristics of effective language teachers as perceived by low and high proficiency students. European Journal of Social Sciences, $31(3), 425-438$

[38] World Bank (2011) Improving the Quality and Equity of
Basic Education in Turkey: Challenges and Options, Washington DC: The World Bank Human Development Department, Europe and Central Asia Region. (Report No: 54131-TR). Retrieved from http://www-wds.worldbank.org/ external/default/WDSContentServer/WDSP/IB/2013/02/20/0 00333037_20130220112531/Rendered/PDF/541310SR0P10 7700Quality0Report02011.pdf

[39] Yilmaz, A. (2011). Quality problem in teaching profession: Qualities teacher candidates feel to be required of teachers. Educational Research and Reviews, 6(14), 812-823. 